\title{
Strongly Agree
}

National Cancer Institute

\section{Source}

National Cancer Institute. Strongly Agree. NCI Thesaurus. Code C104475.

Intense concurrence. 